\title{
Anticorrosive and physicochemical properties of modified phosphate pigments
}

\author{
Katarzyna Przywecka ${ }^{1 *}$, Barbara Grzmil ${ }^{1}$, Krzysztof Kowalczyk ${ }^{2}$ \\ ${ }^{1}$ West Pomeranian University of Technology, Szczecin, Faculty of Chemical Technology and Engineering, Institute of \\ Inorganic Chemical Technology and Environment Engineering, Piastów Ave. 42, 71-065 Szczecin, Poland \\ ${ }^{2}$ West Pomeranian University of Technology, Szczecin, Faculty of Chemical Technology and Engineering, Polymer Institute, \\ Piastów Ave. 42, 71-065 Szczecin, Poland \\ *Corresponding author: e-mail: katarzyna.przywecka@zut.edu.pl
}

\begin{abstract}
Many studies have been carried out in the direction of improvement of the effectiveness of commonly utilized phosphate corrosion inhibitors. For this purpose various types of modifications are realized, e.g. introduction of different cations to the pigment composition or replacement of phosphate anions with others. In the presented work, anticorrosive pigments containing calcium hydrogen phosphate, and/or calcium hydroxyphosphate, and calcium molybdate were obtained. The phase and chemical composition and the oil absorption number of those materials were determined. The anticorrosive properties were investigated by an electrochemical noise method. The obtained results were compared with previously published studies concerning pigments containing $\left(\mathrm{NH}_{4}\right)_{3} \mathrm{Al}_{2}\left(\mathrm{PO}_{4}\right)_{3}$ and/or $\mathrm{AlPO}_{4}$, and $\mathrm{CaMoO}_{4}$. It was found that the pigment containing only calcium molybdate(VI) is not an effective corrosion inhibitor. However, the pigments comprising a mixture of $\mathrm{CaHPO}_{4}$ and $\mathrm{CaMoO}_{4}$ exhibited good anticorrosive properties and they were characterized by higher effectiveness in the corrosion protection than compared materials.
\end{abstract}

Keywords: anticorrosive pigments, modified phosphates, calcium molybdate, electrochemical noise test.

\section{INTRODUCTION}

Corrosion of metals is one of the major processes that causes huge economic losses in many branches of industry ${ }^{1}$. Statistics show that $90 \%$ of damage to ship hulls is caused by this phenomenon ${ }^{2}$. Corrosion of reinforcing steel placed in the concrete is also a big problem ${ }^{3}$. According to the data, corrosion is the second largest reason of failure of the pipelines transporting, for instance, natural gas or water ${ }^{4}$.

At the present time, the utilization of coatings containing anticorrosive pigments is one of the cheapest and effective methods of protection against corrosion. There have been many studies performed in this area and there is also an ongoing search for novel materials that would work as the corrosion inhibitors. Phosphate pigments have been widely reported in the literature with regard to this issue, in particular, zinc phosphate, which is considered as a precursor of phosphate pigments ${ }^{5,6}$. Until recently, it has been successfully used as a substitute for pigments containing lead or chromates(VI). Nevertheless, according to the literature, its modification to improve the anticorrosive properties by changing cation and/or anion is highly advisable ${ }^{7-9}$. Another reason to replace zinc phosphate with other compounds is reported the toxic effect on the aquatic environment of this pigment ${ }^{10}$. Over the years, many studies have been performed on the modification of already available pigments. It may be the introduction of other elements, particle size reduction or the replacement of phosphate anion with the others ${ }^{11-21}$.

In the presented work the experiments were performed in order to reduce the content of phosphates in the pigments by the addition of calcium molybdate as an alternative corrosion inhibitor in a mixture with calcium phosphate. According to the literature survey, calcium molybdate is safe for the environment because it does not dissolve in water and the molybdate anion $\left(\mathrm{MoO}_{4}{ }^{2-}\right)$ exhibits a similar action to the chromate anion
$\left(\mathrm{CrO}_{4}{ }^{2-}\right)^{22}$. The obtained results were compared with previously published studies on aluminum phosphates modified with ammonium, molybdenum and calcium ${ }^{23}$.

\section{EXPERIMENTAL}

\section{Materials and methods}

For preparing pigments consisting of calcium phosphate and calcium molybdate, reagent grade substrates such as: $85 \mathrm{wt} \% \mathrm{H}_{3} \mathrm{PO}_{4}$ (POCH Basic, Gliwice, Poland), $\left(\mathrm{NH}_{4}\right)_{6} \mathrm{Mo}_{7} \mathrm{O}_{24} \cdot 4 \mathrm{H}_{2} \mathrm{O}$ (POCH Basic, Gliwice, Poland), $\mathrm{CaCl}_{2} \cdot 6 \mathrm{H}_{2} \mathrm{O}$ (POCH Basic, Gliwice, Poland) and an aqueous, $28.5 \mathrm{wt} \% \mathrm{NaOH}$ solution (CHEMPUR, Piekary Śląskie, Poland) were utilized.

The syntheses were carried out in the unpressurized reactor at ambient temperature. A solid ammonium molybdate was added into an aqueous solution of phosphate acid and stirred until a clear solution was obtained. Subsequently, calcium chloride in the form of an aqueous solution was dosed to the reactor. The molar ratios of $\mathrm{Ca}^{2+}: \mathrm{PO}_{4}{ }^{3-}: \mathrm{MoO}_{4}{ }^{2-}$ in the substrates in the consecutive experiments were: 1:1:0, 1:0.75:0.25, 1:0.5:0.5, 1:0.25:0.75 and 1:0:1. The $\mathrm{pH}$ of the reaction mixture was adjusted to the desired value with an aqueous solution of sodium chloride, and the process was continued for 30 minutes at constant stirring velocity. The solid phase was separated from the liquid phase using a vacuum filter followed by washing with distilled water three times (the ratio of the liquid phase to the solid phase was 2:1). The final stage of the process was drying the precipitate for $3 \mathrm{~h}$ at $105^{\circ} \mathrm{C}$.

\section{Characterization methods}

The phase composition of obtained materials was studied with X-ray diffraction $(\mathrm{CuK} \alpha$ radiation, Empyrean PANalytical). The identification of the crystalline phases was performed using HighScore+ software and the ICDD PDF-4+ 2016 database. The calcium and molybdenum 
content was determined by ICP-AES technique (Optima 5300 DV, Perkin-Elmer) and the content of phosphates was determined spectrophotometrically (Spekol 11. Carl Zeiss Jena). The oil absorption number (amount of oil needed for complete wetting of tested substance in the powder form) was measured according to PN-EN ISO 787-5 standard ${ }^{24}$. The anticorrosive properties of obtained pigments were evaluated by an electrochemical noise method $^{25}$, which was described in detail in the previous paper of the authors ${ }^{\mathbf{2 3}}$. The plates made of low-carbon non-alloy steel (CRS SAE 1008/1010, Q-Lab, Germany) were used in this test.

\section{RESULTS AND DISCUSSION}

The series of pigments containing calcium phosphates and calcium molybdate was obtained (Series 1). In the further part of the text, the following acronyms for those materials were introduced: $\mathrm{CP}$ for pigment containing calcium phosphates, CMP for material composed of calcium hydroxyphosphate and calcium molybdate and $\mathrm{CM}$ for pigment consisting of calcium molybdate. The properties of these materials were compared with the properties of previously obtained pigments consisting of aluminum phosphates modified with ammonium, calcium and molybdenum (Series 2), named as follows: AACMP for materials comprising ammonium and/or aluminum phosphate and calcium molybdate and AAP for pigment containing only aluminum phosphate modified with ammonium. Table 1. presents the phase composition of all discussed materials as well as their oil absorption number and the molar ratio of individual elements in the products.

With X-ray diffraction analysis, in the materials of Series 1 were identified the crystalline synthesis products such as: $\mathrm{CaMoO}_{4}, \mathrm{CaHPO}_{4}$ and $\mathrm{Ca}_{5}\left(\mathrm{PO}_{4}\right)_{3} \mathrm{OH}$. Calcium hydrogen phosphate was present only in material $\mathrm{CP}$, while in other cases it was a mixture of calcium molybdate and calcium hydroxyphosphate (CMP 1-3). A pigment containing only calcium molybdate (CM) was also obtained in order to verify whether it has good anticorrosive properties. The only crystalline phase identified in the materials of Series 2 was $\mathrm{CaMoO}_{4}$ (AACMP 1-3). The remaining compounds had an amorphous form (probably $\left(\mathrm{NH}_{4}\right)_{3} \mathrm{Al}_{2}\left(\mathrm{PO}_{4}\right)_{3}$ and/or $\left.\mathrm{AlPO}_{4}\right)$. The material AAP entirely consisted of an amorphous phase.
The oil absorption number of products of Series 1 was significantly lower than that of products of Series 2 . The lowest value of this number was determined for material CM which contained only calcium molybdate and amounted to $36 \mathrm{~g} / 100 \mathrm{~g}$ of product. Based on the presented results, it can be noticed that the higher was a fraction of $\mathrm{MoO}_{4}{ }^{2-}$ ion in the product the lower was its oil absorption number. The value of this number was in the range of $36-79 \mathrm{~g} / 100 \mathrm{~g}$ of product for the entire series of materials. The products of Series 2 were characterized by a high oil absorption number in the range from 97 to $127 \mathrm{~g} / 100 \mathrm{~g}$ of product. It was associated with the presence of the amorphous phase in these products.

The contents of particular components in the obtained materials were presented in Figure 1. As can be noticed, in the materials of Series 1 molybdenum plays a significant role in their composition. On the other hand, the products of Series 2 contain from three to five elements, among which molybdenum, calcium and ammonium constitute rather an additive to the main component which is a compound of aluminum and phosphorus. The contents of the particular components in the materials of Series 1 were in the range: 17.72-35.34 wt $\% \mathrm{Ca}, 11.28-31.86 \mathrm{wt} \% \mathrm{Mo}, 1.14-1.60 \mathrm{wt} \% \mathrm{Na}$ and 10.05-45.57 wt $\% \mathrm{P}$ calculated as $\mathrm{P}_{2} \mathrm{O}_{5}$, whereas for pigments of Series 2 they were in the range: $4.82-14.37 \mathrm{wt} \%$ Ca, 3.74-14.42 wt\% Mo, 7.22-15.48 wt\% Al, 1.60-6.60 $\mathrm{NH}_{4}{ }^{+}$and $25.40-46.38 \mathrm{wt} \% \mathrm{P}$ calculated as $\mathrm{P}_{2} \mathrm{O}_{5}$.

The results of the crucial test, namely the determination of anticorrosive properties of the materials concerned were presented in Table 2. The examinations of the anticorrosive properties by an electrochemical noise method demonstrated that the products of Series 1 were characterized by better properties than those of Series 2. However, the charge density for tested material $\mathrm{CM}$ which contained only calcium molybdate was the highest among all analyzed results $\left(103.3 \mathrm{mC} / \mathrm{cm}^{2}\right)$. Hence, a pure calcium molybdate is not a good pigment for application in the anticorrosive coatings. Nevertheless, promising results were achieved in relation to the materials CMP $1-3$, in which calcium molybdate occurs in a mixture with calcium hydroxyphosphate. In the tests performed the charge density for those pigments was within the range of $7.3-9.2 \mathrm{mC} / \mathrm{cm}^{2}$. The product $\mathrm{CP}$ which contained only calcium phosphates $\left(4.7 \mathrm{mC} / \mathrm{cm}^{2}\right)$ exhibited the best inhibiting properties among all tested

Table 1. Phase composition. molar ratios of individual elements in products and oil absorption number of obtained materials

\begin{tabular}{|c|c|c|c|c|c|c|c|c|c|c|c|c|c|c|c|c|c|c|}
\hline \multirow[b]{2}{*}{$\begin{array}{l}\mathscr{d} \\
\frac{\mathscr{L}}{\Phi}\end{array}$} & \multirow{2}{*}{ 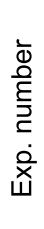 } & \multirow[b]{2}{*}{$\begin{array}{l}\text { Pigment } \\
\text { acronym }\end{array}$} & \multicolumn{4}{|c|}{ Phase composition } & \multicolumn{11}{|c|}{ Molar ratio in products } & \multirow{2}{*}{ 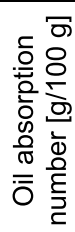 } \\
\hline & & & $\sum_{0}^{0}$ & 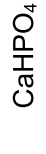 & 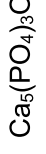 & 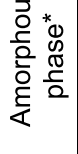 & $\mathrm{Ca}^{2+}$ & : & $\mathrm{MoO}_{4}{ }^{2-}$ & $:$ & $\mathrm{Al}^{3+}$ & : & $\mathrm{Na}$ & : & $\mathrm{NH}_{4}^{+}$ & : & $\mathrm{PO}_{4}^{3-}$ & \\
\hline \multirow{5}{*}{$\begin{array}{c}\bar{\Phi} \\
\frac{\Phi}{\Phi} \\
\omega\end{array}$} & 1 & $\mathrm{CP}$ & $\Delta$ & $\Delta$ & $\Delta$ & $\Delta$ & 1.37 & $:$ & 0.00 & $:$ & 0.00 & $:$ & 0.10 & $:$ & 0.00 & $:$ & 1.00 & 74 \\
\hline & 2 & CMP1 & $\Delta$ & $\Delta$ & $\Delta$ & $\Delta$ & 1.54 & $:$ & 0.27 & $:$ & 0.00 & $:$ & 0.16 & $:$ & 0.00 & $:$ & 1.00 & 79 \\
\hline & 3 & CMP2 & $\Delta$ & $\Delta$ & $\Delta$ & $\Delta$ & 1.95 & $:$ & 0.94 & $:$ & 0.00 & $:$ & 0.22 & $:$ & 0.00 & $:$ & 1.00 & 58 \\
\hline & 4 & CMP3 & $\Delta$ & $\Delta$ & $\Delta$ & $\Delta$ & 4.10 & : & 2.34 & $:$ & 0.00 & $:$ & 0.35 & : & 0.00 & : & 1.00 & 50 \\
\hline & 5 & $\mathrm{CM}$ & $\Delta$ & $\Delta$ & $\Delta$ & $\Delta$ & 1.00 & $:$ & 0.95 & $:$ & 0.00 & $:$ & 0.12 & : & 0.00 & : & 0.00 & 36 \\
\hline \multirow{4}{*}{$\begin{array}{l}N \\
\mathscr{D} \\
\stackrel{\mathscr{V}}{\Phi} \\
\mathscr{D}\end{array}$} & 6 & AACMP1 & $\Delta$ & $\Delta$ & $\Delta$ & $\Delta$ & 1.00 & : & 0.42 & $:$ & 0.75 & : & 0.00 & $:$ & 0.25 & $:$ & 1.00 & 106 \\
\hline & 7 & AACMP2 & $\Delta$ & $\Delta$ & $\Delta$ & $\Delta$ & 0.58 & : & 0.28 & $:$ & 0.75 & : & 0.00 & : & 0.33 & : & 1.00 & 97 \\
\hline & 8 & AACMP3 & $\Delta$ & $\Delta$ & $\Delta$ & $\Delta$ & 0.22 & : & 0.07 & . & 0.78 & : & 0.00 & : & 0.54 & $:$ & 1.00 & 108 \\
\hline & 9 & AAP & $\Delta$ & $\Delta$ & $\Delta$ & $\Delta$ & 0.00 & : & 0.00 & : & 0.88 & : & 0.00 & : & 0.56 & : & 1.00 & 127 \\
\hline
\end{tabular}

*probably $\left(\mathrm{NH}_{4}\right)_{3} \mathrm{Al}_{2}\left(\mathrm{PO}_{4}\right)_{3}$ and/or $\mathrm{AlPO}_{4} ; \Delta-$ the phase was found; $\Delta$ - the phase was not found 


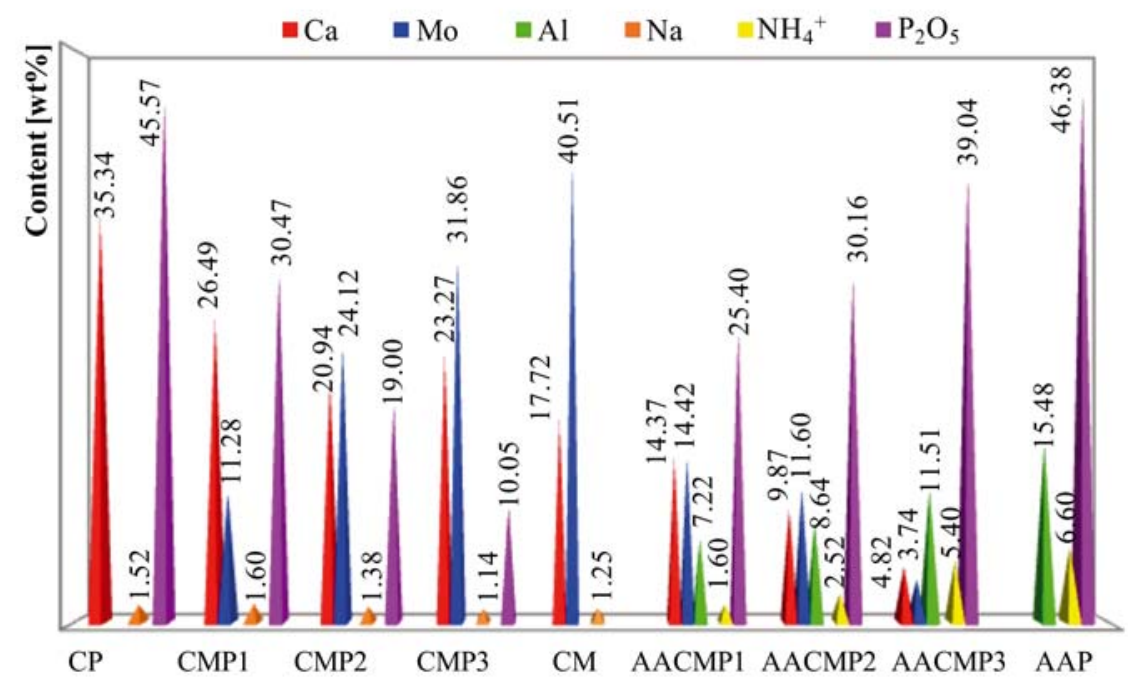

Figure 1. Contents of individual elements in obtained materials

Table 2. The anticorrosive properties determined with an electrochemical noise method

\begin{tabular}{|c|c|c|c|c|c|c|}
\hline \multirow[b]{2}{*}{ 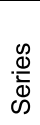 } & \multirow{2}{*}{ 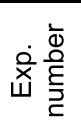 } & \multirow[b]{2}{*}{ Pigment acronym } & \multicolumn{3}{|c|}{ Current density $\left[\mathrm{nA} / \mathrm{cm}^{2}\right]$} & \multirow[b]{2}{*}{ Charge density $\left[\mathrm{mC} / \mathrm{cm}^{2}\right]$} \\
\hline & & & after $6 \mathrm{~h}$ & after $24 \mathrm{~h}$ & average & \\
\hline \multirow{5}{*}{$\begin{array}{l}\bar{\phi} \\
\frac{\Phi}{\infty} \\
\infty\end{array}$} & 1 & $\mathrm{CP}$ & 645.9 & 2.4 & 94.9 & 4.7 \\
\hline & 2 & CMP1 & 97.1 & 48.1 & 114.3 & 7.6 \\
\hline & 3 & CMP2 & 19.2 & 9.3 & 121.0 & 9.2 \\
\hline & 4 & CMP3 & 86.4 & 34.2 & 103.3 & 7.3 \\
\hline & 5 & $\mathrm{CM}$ & 890.6 & 1434.0 & 1196.0 & 103.3 \\
\hline \multirow{4}{*}{ 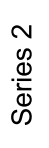 } & 6 & AACMP1 & 423.0 & 232.0 & 339.0 & 29.0 \\
\hline & 7 & AACMP2 & 347.0 & 133.0 & 361.0 & 29.0 \\
\hline & 8 & AACMP3 & 197.0 & 36.0 & 386.0 & 26.0 \\
\hline & 9 & AAP & 1506.0 & 370.0 & 1073.0 & 88.8 \\
\hline
\end{tabular}

materials. In contrast, the materials of Series 2 performed significantly worse on all tests. The charge density for aluminum phosphate modified with molybdenum and calcium and molybdenum ranges from 26.0 to $29.0 \mathrm{mC} /$ $\mathrm{cm}^{2}$, while for the unmodified material AAP the charge density was up to $88.8 \mathrm{mC} / \mathrm{cm}^{2}$. Figure 2. presents the graphs of changes in corrosion current density over time of selected materials, which are CMP2 and CMP3. For comparative purposes, a test in a reference solution, which does not contain any anticorrosive pigment was performed (marked in the graph as a Reference sample). It can be noticed that the current density for solutions containing described pigments is significantly lower than that for reference sample and it decreases from the

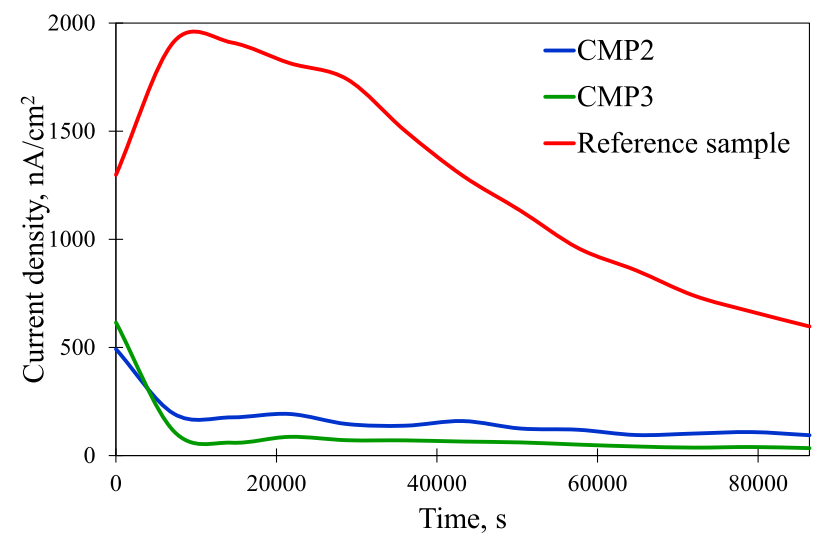

Figure 2. The graphs of changes in corrosion current density over time of selected materials beginning of the test. For a pure solution of $\mathrm{NaCl}$, an increase of current density is visible first.

In assessing the pigment from the point of efficiency in corrosion protection, aside from the values of current density and charge density, is also important the appearance of steel plates themselves after tests. The images of steel plates taken after the corrosion tests were shown in Figure 3. The following photo numbers correspond to experiment numbers presented in tables. For the majority of tested materials, the value of the current density after 6 hours of the test was higher than that after 24 hours. This could be associated with the deposition of a tight layer of corrosion products on the surface of steel plates, which provide additional barrier protection. This does not change the fact that on the images of materials of Series 1 a smaller amount of corrosion products is visible than that on the images of materials of Series 2. For sample No. 1 (CM), a protective layer is visible on the steel plate, owing to which this sample was characterized by the best protective properties among all obtained pigments in the performed tests.

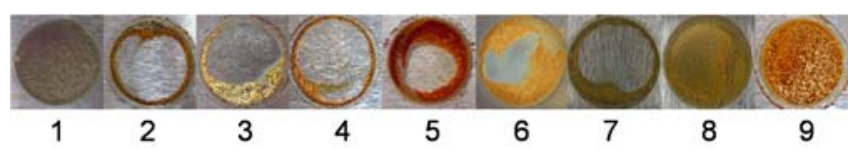

Figure 3. Photos of steel plates after the test of anticorrosive properties of obtained pigments 


\section{CONCLUSIONS}

Anticorrosive pigments obtained within the framework of the planned experiments, contained crystalline calcium hydrogen phosphate and/or calcium hydroxyphosphate as well as calcium molybdate. These pigments were characterized by lower oil absorption number than compared with them aluminum phosphates modified with ammonium, calcium and molybdenum. The products of all experiments were characterized by differentiated phase and chemical compositions which transferred into their anticorrosive properties. It was demonstrated in the studies by an electrochemical noise method that the pigments containing only calcium molybdate or aluminum phosphate are not the effective corrosion inhibitors, while the materials being a mixture of calcium hydroxyphosphate and calcium molybdate exhibited good anticorrosive properties. They were characterized by a higher effectiveness in the protection of steel against corrosion in comparison to aluminum phosphate modified with ammonium, calcium and molybdenum.

This work was supported by the Polish National Research and Development Centre [Project Tango No. TANGO1/266477/NCBR/2015] in the years 2015-2019.

\section{LITERATURE CITED}

1. International Measures of Prevention, Application, and Economics of Corrosion Technologies Study, NACE International, 2016.

2. Zayed, A., Garbatov, Y. \& Guedes Soares, C. (2018) Corrosion degradation of ship hull steel plates accounting for local environmental conditions. Ocean Eng. 163, 299-306. DOI: 10.1016/j.oceaneng.2018.05.047.

3. Balonis, M., Sant, G. \& Isgor, O.B. (2018) Mitigating steel corrosion in reinforced concrete using functional coatings, corrosion inhibitors, and atomistic simulations. Cement Concrete Comp. In Press. DOI: 10.1016/j.cemconcomp.2018.08.006.

4. Shin, S., Lee, G., Ahmed, U., Lee, Y., Na, J. \& Han, Ch. (2018) Risk-based underground pipeline safety management considering corrosion effect. J. Hazard. Mater. 342, 279-289. DOI: 10.1016/j.jhazmat.2017.08.029.

5. Hao, Y., Liu, F., Han, E., Anjum, S. \& Xu, G., (2013) The mechanism of inhibition by zinc phosphate in an epoxy coating. Corr. Sci. 69, 77-86. DOI: 10.1016/j.corsci.2012.11.025.

6. Hernández, M., Genescá, J., Uruchurtu, J., Galliano, F. \& Landolt, D. (2006) Effect of an inhibitive pigment zincaluminum-phosphate (ZAP) on the corrosion mechanisms of steel on waterborne coatings. Prog. Org. Coat. 56(2-3), 199-206. DOI: 10.1016/j.porgcoat.2006.05.001.

7. Naderi, R. \& Attar, M.M. (2009) The inhibitive performance of polyphosphate-based anticorrosion pigments using electrochemical techniques. Dyes Pigm. 80(3), 349-354. DOI: 10.1016/j.dyepig.2008.08.002.

8. Deyá, M.C., Blustein, G., Romagnoli R. \& del Amo, B. (2002) The influence of the anion type on the anticorrosive behaviour of inorganic phosphates. Surf. Coat. Technol. 150(23), 133-142. DOI: 10.1016/S0257-8972(01)01522-5.

9. Naderi R. \& Attar M.M. (2009) Electrochemical study of protective behavior of organic coating pigmented with zinc aluminum polyphosphate as a modified zinc phosphate at different pigment volume concentrations. Prog. Org. Coat. 66(3), 314-320. DOI: 10.1016/j.porgcoat.2009.08.009.

10. Regulation (EC) No 1272/2008 of the European Parliament and of the Council of 16 December 2008 on classification, labelling and packaging of substances and mixtures, amending and repealing Directives 67/548/EEC and 1999/45/EC, and amending Regulation (EC) No 1907/2006.
11. Molina, J., Puig, M., Gimeno, M.J., Izquierdo, R., Gracenea, J.J. \& Suay J.J. (2016) Influence of zinc molybdenum phosphate pigment on coatings performance studied by electrochemical methods. Prog. Org. Coat. 97, 244-253. DOI: 10.1016/j.porgcoat.2016.04.029.

12. Przywecka, K., Grzmil, B., Kowalczyk, K. \& SreńscekNazzal J. (2018) Studies on preparation of phosphate pigments for application in composite protective coatings. Prog. Org. Coat. 119, 44-49. DOI: 10.1016/j.porgcoat.2018.02.009.

13. Alibakhshi, E., Ghasemi, E. \& Mahdavian M. (2014) Sodium zinc phosphate as a corrosion inhibitive pigment. Prog. Org. Coat. 77, 1155-1162. DOI: 10.1016/j.porgcoat.2014.03.027.

14. Puig, M., Gimeno, M.J., Gracenea, J.J. \& Suay J.J. (2014) Anticorrosive properties enhancement in powder coating duplex systems by means of ZMP anticorrosive pigment. Assessment by electrochemical techniques. Prog. Org. Coat. 77(12A), 1993-1999. DOI: 10.1016/j.porgcoat.2014.04.031.

15. El-Hamid, D., Blustein, G., Deyá, M., del Amo, B. \& Romagnoli R., The anticorrosive performance of zinc-free non-toxic pigment for paints. Mater. Chem. Phys. 127(1-2), 353-357. DOI: 10.1016/j.matchemphys.2011.02.018.

16. Karekar, S.E., Bhanvase, B.A., Sonawane, S.H., Deosarkar, M.P., Pinjari, D.V. \& Pandit, A.B. (2015) Synthesis of zinc molybdate and zinc phosphomolybdate nanopigments by an ultrasound assisted route: Advantage over conventional method. Chem. Eng. Process. 87, 51-59. DOI: 10.1016/j.cep.2014.11.010.

17. Bhoge, Y.E., Patil, V.J., Deshpande, T.D. \& Kulkarni, R.D. (2017) Synthesis and anticorrosive performance evaluation of zinc vanadate pigment. Vacuum 145, 290-294. DOI: 10.1016/j.vacuum.2017.08.047.

18. Kowalczyk, K., Łuczka, K., Grzmil, B. \& Spychaj, T. (2012) Anticorrosive polyurethane paints with nano- and microsized phosphates. Prog. Org. Coat. 74(1), 151-157. DOI: 10.1016/j. porgcoat.2011.12.003.

19. Roselli, S.N., Lendvay-Györik, G., Mészáros G., Deyá C. \& Romagnoli R. (2017) Anticorrosive water borne paints free from zinc and with reduced phosphate content. Prog. Org. Coat. 112, 27-36. DOI: 10.1016/j.porgcoat.2017.04.023.

20. Eduok, U., Suleiman, R., Gittens, J., Khaled, M., Smith, T.J., Akid, R., El Ali, B. \& Khalil, A. (2015) Anticorrosion/ antifouling properties of bacterical spore-loaded sol-gel type coating for mild steel in saline marine condition: a case of termophilic strain of Bacillus licheniformis. RSC Adv. 5(114), 93818-93830. DOI: 10.1039/C5RA16494J.

21. Eduok, U., Suleiman, R., Khaled, M. \& Akid, R. (2016) Enhancing water repellency and anticorrosion properties of a hybrid silica coating on mild steel. Prog. Org. Coat. 93, 97-108. DOI: 10.1016/j.porgcoat.2016.01.006.

22. Eduok, U. \& Szpunar J. (2018) Ultrasound-assisted synthesis of zinc molybdate nanocrystals and molybdatedoped epoxy/PDMS nanocomposite coatings for $\mathrm{Mg}$ alloy protection. Ultrason. Sonochem. 44, 288-298. DOI: 10.1016/j. ultsonch.2018.02.036.

23. Łuczka-Wilk, K., Grzmil, B., Kowalczyk, K., Kic, B. \& Przywecka, K. (2017) Pigmenty fosforanowe zawierające amon, glin, wapń i molibden do zastosowań w kompozycjach powłok ochronnych. Przem. Chem. 96/12, 2527-2531. DOI: 10.15199/62.2017.12.27.

24. International Organization for Standarization. (1980). General methods of test for pigments and extenders. Part 5: Determination of oil absorption value. ISO 787-5:1980.

25. Loto, C.A. (2012) Electrochemical Noise Measurment Technique in Corrosion Research. Int. J. Electrochem. Sci. 7, 9248-9270. 